\title{
Young Student's Perspective of Male Teacher: A Case Study of Semarang City, Indonesia
}

\author{
Yuli Kurniawati Sugiyo Pranoto ${ }^{1}$, Sugiyo ${ }^{2}$, Deni Setiawan ${ }^{3}$, and Farid Ahmadi ${ }^{4}$ \\ \{yuli.kurniawati.sp@mail.unnes.ac.id ${ }^{1}$, sugiyo@mail.unnes.ac.id ${ }^{2}$, deni.setiawan@mail.unnes.ac.id ${ }^{3}$ \}
}

Universitas Negeri Semarang, Semarang, Indonesia ${ }^{1,2,3}$

\begin{abstract}
This qualitative phenomenological study reflects eight students' perception of favorite male teacher in Semarang, Indonesia as expressed in their drawings. It conducts with structured interviews to find out the drawings' meaning to them and why they draw them. The data are analyzed and their general themes are determined. Time series is conducted in regard to time triangulation. The study describe eight categories, namely general, sex, body size, body movement and facial expression, physical characteristics, physical properties, space, and physical activities. The reason for the students to like their male teacher is based on social competence, personality, and professional competence. The study serve to be initiative in methodology field that it is possible for a research to engage young children as active participants in consideration of methodology and data collection technique. This study provides suggestions to the government to consider more male teacher at ECEC level.
\end{abstract}

Keywords: perception, competence, young student, male teacher, Semarang-Indonesia

\section{Introduction}

Throughout Indonesia, including Semarang City, the highest percentage of female teachers is with Kindergarten (TK) of more than $96 \%$, while the percentage of male teachers in Kindergarten is less than 5\%. Becoming Kindergarten teacher is mostly desired by women instead of men. In most of Europe countries, there are only 1-4\% male teachers in Early Childhood Education [1] and 8\% in Denmark and Spain [2],[1]. All this time, there are many studies and interviews regarding the reasons of low percentage of male educators in early childhood education which are low salary, lack of social status, fear of accusation of child abuse, and men's lack of field friendship [3]. On the other hand, however, promotion to present male figure in Early Chilhdood Education and Care (ECEC) field has spread throughout the world. [4] assert that there is not sole reason to prevent men from working with young children.

There are many differences between male and female teachers, but not to differentiate both of them. The question is then how gender difference makes teaching style and learning output differ. Local, national and international level studies pay high attention to the academic achievement between male and female students [5], [6], [7], [8], [9]. Meanwhile, a study conducted by [10] shows that female teachers tend to use calm game and focus on social development, while male teachers tend to engage students to get involved in physical game and his teaching practice and use humor [11] and by [12]. Many male teachers acknowledge that they have altruistic impetus in themselves like helping others who encourage them to get 
into the education world [13]. Considering that goodness is with both male and female teachers, they need to cooperate with young children, since these children will learn different characteristics brought into class by male and female teachers. At this point, it is necessary to emphasize that before getting to the issue of whether it is necessary to add male teachers to ECEC, it is necessary for us to conduct a study to explore how students' perception of male teacher is.

Children start to interact with friends and teachers at school [14], [15]. For this reason, one of the important factors to affect the success and efficiency of preschool education is teacher [16]. No matter how good or qualified a curriculum is designed, it is impossible to optimize children development when the teachers who apply it are incompetent [17]. Teacher's competence is a set of knowledge, skill and attitude mastered and internalized by teacher or lecturer in implementation of professional tasks [18], consists of pedagogic, professional, personal and social competencies.

It is reasonable that a teacher is to build harmonious relationship with his students in order to enhance learning effectiveness [19]. Children's positive perception of their teacher will reduce the level of depressive symptom and enhance their self-regard, and vice versa [20]. Teacher's support may help students encounter stress condition they experience and anticipate adaptation difficulty risk [21], [22]. How children perceive their relationship with teacher is influenced by gender [23].

Based on previous findings above, this study reflects young children's perception of male teacher. This indirectly serves to be a study material to evaluate the reflection of male teacher's educational practice during learning process. This reflection is expressed by students, in this case young children, through their drawing. In their series of human figure drawing, children reflect something most interesting in their drawing [24], [25], [26]. Children's drawing and their artistic activities are often a relatively communicative instrument because of their cognition and verbal experience are limited. Drawing allows them to feel relaxed, get to know their environment and test themselves [24], and to develop various skills, such as academic skill, tolerance ability and feeling expression [27]. Children view the world as is. Their perception of their world is represented in their drawing [28], [29]. Children's ideas or thinking, feeling and enthusiasm of occurrence and something are presented in their drawing [24] [28][29].

\subsection{Research objective}

This research aims at exploring young students' perspective of male teacher in Semarang City, Indonesia. The research's question is: "How is male teacher's profile from the perspective young students?"

\subsection{Students' Perception of Teacher}

Perception is one of the abilities in meta cognition monitoring. Meta cognition refers to the concept of superordinate, which consists of two components of knowledge and monitoring (based on experience in the form of memory, perception, problem solving, etc.) and regulation (skill) [30]. A research shows that meta cognitive skill arises when children are 8-10 years old, preceded by cognitive skill like theory of mind (ToM) [31]. The research conducted by [32] observes preschool children in a natural setting (their kindergarten) and finds this children's meta cognitive knowledge. Moreover, [33] find toddlers' memory-monitoring skill. 
Furthermore, perception itself is an important psychological aspect to humans in response to the existence of various surrounding aspects and symptoms. Western figures like [34] and [35] have long beforehand defined perception as "...essentially the interface between the outer and inner worlds". In line with the view, [36] states that perception is a process to organize and integrate stimuli received by organism or individual so that they become something meaningful, and is individual's integrated activities. Previous study revealed that a change in the ability to monitor and regulate children's mental operation is related to gender [23] [37].

\section{Research Method}

\subsection{Research type}

Qualitative design and phenomenological model approach are employed to describe how students' perception of favourite male teacher expressed in their drawing is. Phenomenology is able to outline the description of an individual's conscious experience of a phenomenon [38].

\subsection{Research subjects}

The research subjects are 8 children of kindergarten age (5-6 years old) who respond that their favorite teacher is male teacher.

\subsection{Data collection technique}

Drawing activity. In children's drawing analysis, the important phenomenological point here is to emphasize the meaning and build the view of drawer in his context and world [29]. Drawing activity becomes a popular and effective technique in researches which involve young children [39] [40][41]. Drawing allows children to express their perspective, imagination and interpretation to the world [42]. The researcher holds a brief dialog with children of what to be performed and gives instruction as follows: "Could each of you please draw about your favourite teacher". The researcher provides crayon and A3 sized drawing paper to each of the children.

Interview. In the process of children's drawing analysis, the research should re-ask the children of the meaning of their drawing to them [43] and why they draw it [41]. The result of recording is copied into verbatim form for further analysis.

\subsection{Data analysis technique}

The collected data are analyzed and interpreted by making code list, percentage, and frequency value. The data are then compared one to another for higher data reliability and validity. The data are analyzed one by one in order to conclude a general theme [44]. For reliability of data analysis, the researcher employs two different independent analyses. 


\section{Result And Discussion}

\subsection{Teacher's Profile}

We may conclude that 8 out of the 47 children state that their favorite teacher is male teacher. From these 8 children, 1 of them is female student. Based on the result of analysis on 10 children's drawings in regard to male favorite teacher, the categories are described in more detail below:

Children's perception of teacher. The analysis result shows that 4 out of the 8 children (50\%) express their perception of male teacher in the form of physically incomplete humanshaped drawing. Young children are focus on certain parts instead, for example, smiling face. The remaining 4 out of the 8 children $(50 \%)$ still express their perception into cartoon or other object like car and rocket vehicle, as shown in the figure below. This is driven by their direct observation on their daily life, television, interest in items, interest in figures, and attempt to expand their imagination.

Children's perception of teacher's sex. For this category, all drawings conform to the fact, that the children draw pursuant to the teacher's sex (male). With limited drawing, 4-7 years old children are able to coordinate their mind, emotion and motor ability. During this childhood, children recognize and draw pursuant to the fact, extension of fact, and deepening of imagination.

Physical appearance. 7 out of 8 children $(87.5 \%)$ draw their teacher in non-detailed costume. There are some reasons for this, first, their motor ability is still limited; second, their interest to draw detailed costume is still limited; and third, transition of period from drawing random lines towards more clear form. The movement of making random lines lessens, replaced with lines which represent certain form.

Body size. Some children are able to draw pursuant to real size, but some others draw in smaller or bigger than real size. In this age, children prioritize the moving parts of an object. They tend to ignore the proportion one to another part in drawing. They are interested more to display arms movement, head movement, legs movement and happy facial expression.

Body movement and facial expression. The children's drawings of teacher's expression show various expressions, from smile expression (5 out of 8 children), serious expression (1 out of 8 children) to no expression ( 2 out of 8 children). Smile expression is drawn by 5 out of 8 children, showing domination of their interest in and focus on teacher's facial expression. It can certainly reflect that the children are able to coordinate their mind, emotion and motor ability, which arise as the consequence of observation they perform. Logically, preschool teachers will smile more frequently and show happy facial expression, and the message will be caught well by most of the children.

Physical properties. 6 out of 8 children draw with physical limitation, random-style hair and no hair categories. This proves that children's arms movement to make random lines lessens, replaced with lines which represent form better. Drawing human or moving items is more difficult than drawing inanimate or immobile form. The children start to record teacher's activities and express them into drawing. 
Space. The setting or space in children's drawing covers school yard and school garden. This shows children's experience and observation when they are playing with male teacher, which is: outdoor. Male teacher tends to like playing outdoor [10], [11], [12]. The children also start to record and reflect driving, role play and placement of teacher in classroom activities.

Action. The children record every event they experience at school, including their observation of teacher, including standing and performing activities during learning and teaching activity. It is motor limitation which restricts children's ability to reflect any event in detail, so that they focus more on one fragment of illustration, including standing, smiling and teaching activities.

Based on study conducted by [45], children's drawing is classified into ten categories. This present study revealed two categories not present in the children's drawings, namely object in hand and object in classroom. This occurs because the figure represented in this research focuses on male teacher.

The respondents' responses to the question of what is liked about male teacher may be classified into three competencies, namely:

Social and personal competencies. Social competence is teacher's ability to communicate and socialize effectively with students, co-educators, education staff, students' parents/guardian, and surrounding society. Personal competence is personal ability which reflects personality which is established, stable, mature, wise and authoritative, exemplary to students, and of good character. Some of the children's responses when they are asked of what they like from their teacher are:

"good and not fierce" (N, male, 5 years old)

"good and never gets angry" (P, male, 5 years old)

Professional competence. Professional competence is extensive and deep mastery of learning materials, covering mastery of subject curriculum materials at school and scientific substance covering the materials, and mastery of scientific structure and methodology. The learning management ability is supported with class management, learning material mastery, teaching strategy and learning media usage. Some of the children's responses when they are asked of what they like from their teacher are:

"... and the drawings are good" (Z, 6 yo)

"the drawings are good" (E, 5 yo)

Children assess their teacher based on professional competence, for example, block playing and drawing abilities. This conforms to the research result that young students evaluate their teachers based on the attitudes and behaviors shown by the teachers [46]. [47] emphasize that relationship between teacher and student shows emotional signals, to that children will find it easier to reflect their negative feelings, challenges perceived, and deepest feelings through drawing, compared to expressing their opinion directly (verbally).

However, out of the four competencies a teacher must have, young children tend to evaluate their teacher only on two competencies: personal/social and professional competencies. This conforms to some opinions below, that the relationship between student and teacher influences learning and teaching process in classroom, in a positive or negative environment. In this childhood period, when a learning model is effective, children will be 
impressed by teacher's behaviors. Teachers influence students with how they behave and through their personality.

\section{Conclusion}

The study indicates eight categories of children perception of their male teacher, namely perception in general, sex, body size, body movement and facial expression, physical characteristics/appearance, physical properties, location/space and physical activity. Students asses their favourite male teacher based on social/personal competencies and professional competenc 


\section{References}

[1] Sumsion, J.: Male Teacher in Early Childhood Education: Issue and Case Study. Early Childhood Research Quarterly. Vol. 20, pp. 109-123 (2005)

[2] Jensen, J. J: Men as workers in childcare services. European Commission Network on Childcare and Other Measures to Reconcile Employment and Family Responsibilities. (1996).

[3] Klecker, B. M., \& Loadman, W. E.: Male elementary school teachers ${ }^{\text {ee }}$ ratings of job satisfaction by years of teaching experience. Education. Vol. 119, 504-513 (1999).

[4] Ballema, Gretchen E., Dievendorf, Mary J., Huberts, Hillary K., Mick, JudyA., Muntter, Laurie A., \& Ward, Karen T.: Recommendations for improving the recruitment of male early childhood education professionals. Masters Project submitted to the Faculty of the School of Education, Advanced Studies in Education at Grand Valley State University, Grand Rapids, Michigan, December (1999).

[5] Peeters, J.: Including men in early childhood education: Insights from the European experience. NZ Research in Early Childhood Education Journal, Vol. 10, pp. 15-24 (2007).

[6] Lloyd, T.: Boys' Underachievement: What Schools Think and Do. A University of Ulster Research Project Funded by the Department of Education and Northern Ireland Office. November. Retrieved from http://www.socsci.ulster.ac.uk/sociology/research/y\%20publications/Boys\%20 underachievement.pdf (2009).

[7] Lloyd, T.: Boys' Underachievement in Schools: Literature Review. Retrieved from http://www.boysdevelopmentproject.org.uk/downloads/reports/Boys $\% 20$ and $\%$ 20underachievement $\% 20$ literature $\% 20$ review\%20edited\%20in\%20pdf.pdf (2011).

[8] Moran, L.: Quarter of All Primary Schools Have No Male Teachers Despite More Men Entering Profession. Daily Mail, September 2. Retrieved from http://www.Gender and Education 259dailymail.co.uk/news/article-2032970/Quarter-primary-schools-NOmale-teachers-despitemen-enteringprofession.html\#ixzz2JwpQjSL8 (2011).

[9] Parity.: Is Action Overdue on Boys' Academic Underachievement? Retrieved from http://www.parityuk.org/Briefing/BoysEducPaperRev1b.pdf (2013).

[10] Sandberg, Anette. \& Pramling-Samuelsson, Ingrid. An Interview Study of Gender Difference in Preschool Teachers' Attitudes Toward Children's Play. Early Childhood Education Journal 32(5):297-305. DOI: 10.1007/s10643-005-4400-x. (2005).

[11]Rentzou, K., and K. Ziganitidou.: Greek male early childhood educators: Self and societal perceptions towards their chosen profession. Early Years,. Vol. 29, No. 3, pp. 271-279, (2009).

[12] Vandenbroeck, M., \& Peeters, J.: Gender and professionalism: a critical analysis of overt and covert curricula. Early Child Development and Care. Vol. 178(7e8), pp. 703715, (2008).

[13] Robinson, B. E., \& Hobson, C. M. Men in day care: You've come a long way, buddy!. In Child and Youth Care Forum. Vol. 7, No. 2, pp. 156-163. Springer Netherlands (1978).

[14] Margetts, K.: Personal, Family and Social Influences on Children's Early School Adjustment. Paper Presented at the AECA Biennial Conference, Hobart, 10-13 July (2003). 
[15] Oktay A. and Unutkan Ö.P.: New Approaches in Development and Education in Early Childhood (Prepared by Müzeyyen Sevinç), Readiness for Primary Education and Comparison of Pre-School Education and Primary Education, Morpa Kültür Yayınları, İstanbul, pp. 145-155 (2005).

[16] Alkan, C.: Educational Psychology. Ankara, Turkey: Ani Publisher (2005).

[17] Saracaloglu, A.S., Kumral, O., \& Kanmaz, A.: Anxieties, academic motivation levels and competencies at teaching profession of students at secondary education fields teaching nonthesis master program. Yuzuncu Y1l Universitesi Egitim Fakultesi Dergisi. Vol. 6, No. 2, pp. 38-54 (2009).

[18] Act No 14 of 2005 on Teacher and Lecturer

[19] Çetin, Ş.: Establishment of the profession of teaching attitude scale (the study for validity and confidence). Gazi University Journal of Industrial Arts Education. Vol. 18, pp. 28-37 (2006).

[20] Davis, H. A.: Conceptualizing the role and influence of student teacher relationships on children's social and cognitive development. Educational Psychologist. Vol. 38, No. 4, pp. 207-234; (2003).

[21] Midgley, C., \& Edelin, K. C. Middle school reform and early adolescent well-being: The good news and the bad. Educational Psychologist. Vol. 33, No. 4, pp. 195-206 (1998).

[22] Pianta, R. C.: Enhancing relationships between children and teachers. Washington, DC: American Psychological Association; Pianta, Stuhlman, \& Hamre. (2002)

[23] Dee, T.:'Teachers and the gender gaps in student achievement'. Journal of Human Resources (2007)

[24] Artut, K.: Art educations's theories and methods (third edition). Ankara: Anı Press (2004)

[25]Celebi-Öncü, \& Darica, N.: Examining the Effects of Visual Arts Education of 5-6 Years Old Orphanage Children, 10th EECERA Conference, 31 August- 2 September 2000, London, England (2000).

[26] Koppitz, E. M.: Psychological Evaluation of Human Figure Drawings by Middle School Pupils. New York: Harcourt Brace Jovanovich (1984).

[27] Wardle, F.: Introduction to Early Childhood Education. USA: Allyn and Bacon (2003).

[28] Malchiodi, C. A.:Using drawing as intervention with traumatized children. Trauma and Loss: Research and Intervention. Vol. 1, No. 1, pp. 21-28, (2001).

[29] Yavuzer H.: Child paintings, children paintings recognition. Istanbul, Turkey: Remzi Bookstore (2007).

[30]Lyons, K. E., \& Ghetti, S.: Metacognitive Development in Early Childhood: New Questions about Old Assumptions. A. Efklides and P. Misailidi (eds.), Trends and Prospects in Metacognition Research, DOI: 10.1007/978-1-4419-6546-2_12. (2010).

[31] Whitebread, D., Almeqdad, Q., Bryce, D., Demetriou, D., Grau, V., \& Sangster, C.: Metacognition in Young Children: Current Methodological and Theoritical Developments. A. Efklides and P. Misailidi (eds.). Trends and Prospects in Metacognition Research, DOI: 10.1007/978-1-4419-6546-2_11. (2010).

[32] Demetriou, D., \& Whitebread, D.: Theory of Mind and Metacognitive Knowing: Have We been Investigating Similar Constructs Without Realizing It? Greece: Ioannina (2008).

[33] Balcomb, F., \& Gerken, L.: Three-yearold Children can Access Their Own Memory to Guide Responses on a Visual Matching Task. Developmental Science. Vol. 11, pp. 750-760 (2008). 
[34] Marr, D.: Vision. San Francisco: Freeman (1982).

[35] Triesman, A., \& Gelade, G.: A feature integration theory of attention. Cognitive Psychology. Vol.12, pp. 97-136 (1980).

[36] Bimo, Walgito. Pengantar Psikologi Umum. Jakarta: Andi (2004).

[37] Quazad, A., \& Page, L.: Students' Perceptions of Teacher Biases: Experimental Economics in Schools. Centre for the Economics of Education, Discussion Paper. No. 133 (2012).

[38] Christensen, B. L., Johnson, R. B., \& Turner, L. A.: Research Methods, Design and Analysis. Boston: Pearson (2011).

[39] MacNaughton, G., Smith, K \& Lawrence, H.: ACT Children's Strategy: Consulting with children birth to eight years of age: Hearing Young Children's Voices. Children's Services Branch, ACT Department of Education, Youth and Family Services, Canberra (2003).

[40] Davis, J. M.: Understanding the meaning of children: A reflexive process. Children \& Society. Vol. 12, pp. 325-335 (1998).

[41] Punch, S.: Research with children: The same or different from research with adults?', Childhood. Vol. 9, No. 3, pp. 321-341 (2002b).

[42] Thomas, N \& O'Kane, C.: Discovering what children think: Connections between research and practice. British Journal of Social Work. Vol. 30, No. 6, pp. 817-833 (2000)

[43] Morrow, V \& Richards, M.: The ethics of Social research with children: An Overview, Children and Society. Vol: 10, pp. 90-105 (1996).

[44] Miles, M. B., \& Huberman, A. M.: An Expanded Source Book Qualitative Data Analysis (2nd Edition). California: Sage Pablications, Inc (1994).

[45] Aykaç, N.: Sense of the Teacher and learning process on the pictures of the primary school students. Education and science. Vol. 164, pp. 298-316 (2012).

[46] Kılıç, Z.: Comparison of Development Skills of the Students Who Took Pre-School Education and the Students Who Did Not Take Pre-School Education According to the Views of the Teachers of the 1st Grade of Primary School. Unpublished Postgraduate Thesis. Beykent University, İstanbul (2008).

[47] Harrison, L. J., Clarke, L., \& Ungerer, J. A.: Children's Drawings Provide a New Perspective on Teacher-Child Relationship Quality and School Adjustment. Early Childhood Research Quarterly. Vol. 22, pp. 55-71. http://dx.doi.org/10.1016/j.ecresq.2006.10.003 (2007). 